Article

\title{
Influence of Dolomite Rock Powder and Iron Tailings Powder on the Electrical Resistivity, Strength and Microstructure of Cement Pastes and Concrete
}

\author{
Yang Liu ${ }^{1,2}$, Wenru Hao ${ }^{2}$, Wei He ${ }^{2,3, *}$, Xia Meng ${ }^{4}$, Yinlan Shen ${ }^{5}$, Tao Du ${ }^{6}$ and Hui Wang ${ }^{7, *}$ \\ 1 CCCC-SHEC Third Highway Engineering Co., Ltd., Xi'an 710016, China; liuyang1984001@163.com \\ 2 School of Civil and Transportation Engineering, Beijing University of Civil Engineering and Architecture, \\ Beijing 102616, China; haowenru1@163.com \\ 3 Beijing Key Laboratory of Urban Underground Space Engineering, School of Civil and Resource Engineering, \\ University of Science and Technology Beijing, Beijing 100084, China \\ 4 Architectural Design and Research Institute of Tsinghua University Co., Ltd., Beijing 100084, China; \\ mengxia@thad.com.cn \\ 5 Faculty of Architecture, Civil and Transportation Engineering, Beijing University of Technology, \\ Beijing 100124, China; shenyinlan@bjut.edu.cn \\ 6 School of Mechanics and Civil Engineering, China University of Mining and Technology, \\ Xuzhou 221116, China; dutaohit@gmail.com \\ 7 School of Civil and Environmental Engineering, Ningbo University, Ningbo 315000, China \\ * Correspondence: hewei@bucea.edu.cn (W.H.); huiwang123@aliyun.com (H.W.)
}

check for updates

Citation: Liu, Y.; Hao, W.; He, W.; Meng, X.; Shen, Y.; Du, T.; Wang, H. Influence of Dolomite Rock Powder and Iron Tailings Powder on the Electrical Resistivity, Strength and Microstructure of Cement Pastes and Concrete. Coatings 2022, 12, 95. https://doi.org/10.3390/ coatings12010095

Academic Editor: Paolo Castaldo

Received: 29 December 2021

Accepted: 12 January 2022

Published: 14 January 2022

Publisher's Note: MDPI stays neutral with regard to jurisdictional claims in published maps and institutional affiliations.

Copyright: (c) 2022 by the authors. Licensee MDPI, Basel, Switzerland. This article is an open access article distributed under the terms and conditions of the Creative Commons Attribution (CC BY) license (https:// creativecommons.org/licenses/by/ $4.0 /)$.

\begin{abstract}
Dolomite rock powder (the waste stone residue in the production of machine-made sand and stone processing) and iron tailings powder formed by mineral processing industry are solid wastes, which occupy land resources, pollute the environment and release toxic substances without reasonable processing. The dolomite rock powder and iron tailings powder composing a large number of active substances could be advantageous to the cement-based materials. In this study, the electrical resistivity of cement paste and concrete was measured. Meanwhile, the influence of dolomite rock powder and iron tailings powder on the compressive strength of concrete was investigated. The electric flux of concrete was determined to estimate the chloride ion permeability. The scanning electron microscope (SEM) and X-ray diffraction were obtained to investigate the hydration of cement paste. Results showed the electrical resistivity of all specimens presented in this order: specimens with iron tailings $<$ specimens with dolomite rock powder $<$ blank specimens $<$ specimens with ground granulated blast-furnace slag (GGBS) < specimens with fly ash. The correlation between electrical resistivity and curing age of cement paste or concrete has been deduced as a quadratic function. The addition of GGBS could improve the compressive strength of concrete. Meanwhile, when the other three types of mineral admixtures were added, $5 \%$ by mass ratio of the total binder materials was the optimum for the compressive strength. The curing ages, the fly ash, the GGBS and $5 \%$ dolomite rock powder or $5 \%$ iron tailings powder demonstrated a positive effect on the chloride ion impermeability. However, when higher dosages of dolomite rock powder or iron tailings powder were added, the effect was the opposite. Finally, the compactness of the microstructure and the $\mathrm{Ca}(\mathrm{OH})_{2}$ of cement paste could be improved by a small dosage of dolomites or iron tailings (less than $5 \%)$.
\end{abstract}

Keywords: dolomite rock powder; iron tailings powder; concrete; electrical resistivity; chloride ion impermeability; scanning electron microscope; X-ray diffraction

\section{Introduction}

Concrete is an important human-made civil engineering material, which has been widely used for many years [1-3]. With the rapid development of housing construction, a large amount of solid waste formed. The accumulation of solid waste without reasonable 
treatment will not only pollute the environment, but also affect the appearance of the city [4]. The recycling of solid waste in building materials provides an innovative idea for the treatment of solid waste $[5,6]$.

Researchers found that the solid wastes like waste fly ash and rice husk ash possessing active substances could promote the hydration process of cement. The addition of waste fly ash and rice husk ash were proven to increase the mechanical strengths and durability of concrete [7-9]. Moreover, the waste fly ash and rice husk ash could improve the corrosion resistance of steel bars in the reactive powder concrete. The main problem with fly ash is that, as we increase the quantity, the hydration reaction is slowed down and the rate of strength gain is reduced. A number of scientists are adding nanoparticles to mitigate this $[10,11]$. Meanwhile, the rice husk ash is produced by burning rice husk. A large amount of carbon dioxide gas will be produced during the production [12,13]. Additionally, commonly used mineral admixtures are in short supply, thus the prices are rising with time. Summarily, other reasonable solid wastes or resources need to be excavated and applied to concrete.

Dolomite rock powder and iron tailings powder are produced by the sand gravel processing industry and metallurgical industry [14]. The accumulation of dolomite rock powder induces the occupation of land. Additionally, the iron tailings powder can pollute the environment and release toxic substances without reasonable processing. Therefore, the treatment and comprehensive utilization of stone powder and iron tailings have become an urgent problem to be solved $[14,15]$. Previous studies pointed out that the addition of an appropriate amount of dolomite rock powder can improve the micropores of concrete and improve the mechanical properties, carbonation and frost resistance of concrete [16,17]. Moreover, the iron tailings have good grindability and a low price. It is technically feasible to use iron tailings powder as concrete mineral admixture [18,19]. Lu et al. [20] found that adding iron tailings powder to cement can improve the compressive strength of concrete. Song Shaomin et al. [21] discovered that adding an appropriate amount of iron tailings powder can improve the chloride ion permeability and carbonation resistance of concrete. The electrical resistivity of cement-based materials can be used to reflect the hydration process of cement and the corrosion resistance of steel bars inner concrete [22-25]. However, little attention was paid to the electrical resistivity of cement-based materials with dolomite rock powder and iron tailings powder. Moreover, the influence of dolomite rock powder and iron tailings powder on the mechanical performance, the electrical property and microscopic mechanism should be studied systematically.

In this study, the electrical resistivity of cement paste or concrete with iron tailings, dolomite rock powder, ground granulated blast-furnace slag and fly ash was studied. Moreover, the following compressive strength and chloride ion permeability were determined. The curing age ranged from 3 days to 210 days. Scanning electron microscopy (SEM) and $\mathrm{X}$-ray diffraction (XRD) were obtained for the mechanism analysis of the properties. This research will provide a basis for the application of these two solid wastes in construction building materials in the future.

\section{Experimental Section}

\subsection{Raw Materials}

The fly ash (FA) was provided by Beijing Jing Ye Da New Building Materials Co., Ltd., Beijing, China, showing the air drying water content of $1.5 \%$, the specific surface area of $385 \mathrm{~m}^{2} / \mathrm{kg}$ and the maximum dry density of $2.21 \mathrm{~g} / \mathrm{cm}^{3}$. Granulated blast furnace slag powder (GGBS) with a density of $2.85 \mathrm{~g} / \mathrm{cm}^{3}$, a specific surface area of $450 \mathrm{~m}^{2} / \mathrm{g}$ and a loss on ignition of $2.1 \%$ produced by Hebei Jintaicheng Environmental Resources Co., Ltd., Xingtai, China, was applied in the experiments. Ordinary Portland cement manufactured by Beijing Jinyu Group Co., Ltd., Beijing, China, was used in the study. The strength grade of ordinary Portland cement is $42.5 \mathrm{MPa}$. The micro powder of iron tailings was produced by Fujian Quanzhou Meiling Group Co., Ltd., Quanzhou, China, was used for manufacturing the specimens. The micro-powder of iron tailings showed a density of 
$3.125 \mathrm{~g} / \mathrm{cm}^{3}$ and a specific surface area of $517 \mathrm{~m}^{2} / \mathrm{kg}$. The dolomite rock powder was provided by Beijing high strength Concrete Co., Ltd., Beijing, China, showing a density of $2.73 \mathrm{~g} / \mathrm{cm}^{3}$ and a specific surface area of $200 \mathrm{~m}^{2} / \mathrm{kg}$.

The natural river sand with a fineness modulus of 2.9 manufactured by Beijing Yugou Co., Ltd., Beijing, China, was used as fine aggregate in this study. The sand belonging to the medium sand possesses the apparent density of $2677 \mathrm{~kg} / \mathrm{m}^{3}$ and bulk density of $1546 \mathrm{~kg} / \mathrm{m}^{3}$. The coarse aggregate used for manufacturing concrete was the crushed limestone produced by Beijing Yugou Precast Concrete Engineering, Beijing, China. The coarse aggregate with the particle sizes of $5-10 \mathrm{~mm}$ and $10-20 \mathrm{~mm}$ and the following mass ratios of $30 \%$ and $70 \%$ were used in this study. Meanwhile, the crushing index, the apparent density and the bulk density of crushed limestone were $5.2 \%, 2800 \mathrm{~kg} / \mathrm{m}^{3}$ and $1650 \mathrm{~kg} / \mathrm{m}^{3}$, respectively. The total mud content of all aggregates was $1.3 \%$. The particle size distributions and chemical compositions are shown in Tables 1 and 2, respectively.

Table 1. Particle passing percentage of the cementitious materials/\%.

\begin{tabular}{ccccccccc}
\hline \multirow{2}{*}{ Types } & \multicolumn{7}{c}{ Particle Size/ $\boldsymbol{\mu m}$} \\
\cline { 2 - 9 } & $\mathbf{0 . 3}$ & $\mathbf{0 . 6}$ & $\mathbf{1}$ & $\mathbf{4}$ & $\mathbf{8}$ & $\mathbf{6 4}$ & $\mathbf{3 6 0}$ & $\mathbf{5 8 0}$ \\
\hline Cement & 0.1 & 1.35 & 3.68 & 23.79 & 39.46 & 94.12 & 100 & 100 \\
Fly ash & 0.49 & 1.54 & 2.93 & 19.54 & 37.9 & 92.99 & 100 & 100 \\
GGBS & 0.31 & 1.78 & 4.2 & 21.85 & 38.68 & 100 & 100 & 100 \\
Dolomite & 0 & 0.58 & 1.45 & 7.14 & 13.01 & 75.91 & 97.41 & 100 \\
Iron tailings & 0.21 & 2.28 & 6.55 & 32.22 & 47.91 & 100 & 100 & 100 \\
\hline
\end{tabular}

Table 2. Chemical composition of the cementitious materials $/ \%$.

\begin{tabular}{ccccccccccc}
\hline Types & $\mathbf{C a O}$ & $\mathbf{S i O}_{\mathbf{2}}$ & $\mathbf{A l}_{\mathbf{2}} \mathbf{O}_{\mathbf{3}}$ & $\mathbf{F e}_{\mathbf{2}} \mathbf{O}_{\mathbf{3}}$ & $\mathbf{M g O}$ & $\mathbf{S O}_{\mathbf{3}}$ & $\mathbf{K}_{\mathbf{2}} \mathbf{O}$ & $\mathbf{M n O}$ & $\mathbf{L o s s}$ \\
\hline Cement & 4.55 & 50.23 & 33.22 & 5.95 & 0.79 & 0.91 & 1.48 & $/$ & 2.81 \\
Fly ash & 4.55 & 50.23 & 33.22 & 5.95 & 0.79 & 0.91 & 1.48 & $/$ & 2.81 \\
GGBS & 42.19 & 27.56 & 15.80 & 0.31 & 7.52 & 2.89 & 0.45 & $/$ & 1.89 \\
Dolomite & 48.62 & 29.67 & 0.72 & 0.47 & 20.17 & 0.05 & 0.18 & $/$ & 0.07 \\
Iron tailings & 14.78 & 47.35 & 5.05 & 23.56 & 1.55 & 2.04 & $/$ & 3.21 & 2.46 \\
\hline
\end{tabular}

\subsection{Characterization Methods}

\subsubsection{Samples Preparation}

The preparation of all specimens was carried according to the mixing proportions of Table 3. The samples of cement paste were manufactured following these steps:

Table 3. Mix proportion of the cement paste or concrete $/ \mathrm{kg} / \mathrm{m}^{3}$.

\begin{tabular}{|c|c|c|c|c|c|c|c|}
\hline Cement & Fine Aggregate & Coarse Aggregate & $\begin{array}{l}\text { Fly } \\
\text { Ash }\end{array}$ & GGBS & Dolomites & Iron Tailings & Water \\
\hline 457 & - & - & - & - & - & - & 146 \\
\hline 434.2 & - & - & 22.8 & - & - & - & 146 \\
\hline 411.3 & - & - & 45.7 & - & - & - & 146 \\
\hline 388.5 & - & - & 68.5 & - & - & - & 146 \\
\hline 434.2 & - & - & - & 22.8 & - & - & 146 \\
\hline 411.3 & - & - & - & 45.7 & - & - & 146 \\
\hline 388.5 & - & - & - & 68.5 & - & - & 146 \\
\hline 434.2 & - & - & - & - & 22.8 & - & 146 \\
\hline 411.3 & - & - & - & - & 45.7 & - & 146 \\
\hline 388.5 & - & - & - & - & 68.5 & - & 146 \\
\hline 434.2 & - & - & - & - & - & 22.8 & 146 \\
\hline 411.3 & - & - & - & - & - & 45.7 & 146 \\
\hline 388.5 & - & - & - & - & - & 68.5 & 146 \\
\hline
\end{tabular}


Table 3. Cont.

\begin{tabular}{|c|c|c|c|c|c|c|c|}
\hline Cement & Fine Aggregate & Coarse Aggregate & $\begin{array}{l}\text { Fly } \\
\text { Ash }\end{array}$ & GGBS & Dolomites & Iron Tailings & Water \\
\hline 457 & 753 & 1080 & - & - & - & - & 160 \\
\hline 434.2 & 753 & 1080 & 22.8 & - & - & - & 160 \\
\hline 411.3 & 753 & 1080 & 45.7 & - & - & - & 160 \\
\hline 388.5 & 753 & 1080 & 68.5 & - & - & - & 160 \\
\hline 434.2 & 753 & 1080 & - & 22.8 & - & - & 160 \\
\hline 411.3 & 753 & 1080 & - & 45.7 & - & - & 160 \\
\hline 388.5 & 753 & 1080 & - & 68.5 & - & - & 160 \\
\hline 434.2 & 753 & 1080 & - & - & 22.8 & - & 160 \\
\hline 411.3 & 753 & 1080 & - & - & 45.7 & - & 160 \\
\hline 388.5 & 753 & 1080 & - & - & 68.5 & - & 160 \\
\hline 434.2 & 753 & 1080 & - & - & - & 22.8 & 160 \\
\hline 411.3 & 753 & 1080 & - & - & - & 45.7 & 160 \\
\hline 388.5 & 753 & 1080 & - & - & - & 68.5 & 160 \\
\hline
\end{tabular}

In order to prepare the cement paste, the NJ-160A cement paste mixer offered by Hebei Yuhong Instrument Equipment Co., Ltd., Cangzhou, China, was used. Firstly, the cementitious materials were added to the mixer and mixed at the mixing speed of $62 \mathrm{r} / \mathrm{min}$ for $1 \mathrm{~min}$. Then, the mixture of water reducer and water was added and mixed at this speed for another $1 \mathrm{~min}$. Finally, all mixtures were mixed at the speed of $140 \mathrm{r} / \mathrm{min}$ for the last two minutes. The fresh cement paste was poured into the molds for manufacturing the specimens of size of $40 \mathrm{~mm} \times 40 \mathrm{~mm} \times 160 \mathrm{~mm}$. The specimens were demolded after cured in the environment with a temperature of $20 \pm 2{ }^{\circ} \mathrm{C}$ and the relative humidity of $40 \%$ for $1 \mathrm{~d}$.

For manufacturing the concrete specimens, all cementitious materials and aggregates were added to the SJD-60 single horizontal shaft concrete mixer manufactured by Cangzhou tiantuo Instrument Equipment Co., Ltd., Cangzhou, China and mixed at the speed of $48 \mathrm{r} / \mathrm{min}$ for $4 \mathrm{~min}$. In this study, six specimens were selected for each experiment. The average value and error bar of each parameter were used for evaluating the properties of specimens.

\subsubsection{Measurement of Electrical Resistivity}

The electrical resistance of specimens was measured after cured in standard curing environment $\left(20 \pm 2{ }^{\circ} \mathrm{C}\right.$ and relative humidity of above $\left.95 \%\right)$ for $3 \mathrm{~d}, 7 \mathrm{~d}, 14 \mathrm{~d}, 28 \mathrm{~d}, 56 \mathrm{~d}$, $180 \mathrm{~d}$ and $210 \mathrm{~d}$. A 16-mesh copper mesh produced by Hebei Haiji Wire Mesh Co., Ltd., Hengshui, China, was used for the test of electrical resistance. The electrical resistivity can be calculated by Equation (1) [26].

$$
\rho=\frac{R S}{L}
$$

Where $R$ means the electrical resistance of specimen, $S$ is the interface area of specimen and $L$ is the length of specimen.

Specimens with sizes of $40 \mathrm{~mm} \times 40 \mathrm{~mm} \times 160 \mathrm{~mm}$ and $100 \mathrm{~mm} \times 100 \mathrm{~mm} \times 300 \mathrm{~mm}$ were used for the determination of electrical resistance of cement paste and concrete, respectively. The electrode sizes for the determination of electrical resistance of cement paste and concrete were $30 \mathrm{~mm} \times 50 \mathrm{~mm}$ and $70 \mathrm{~mm} \times 110 \mathrm{~mm}$. The spacing between two electrodes of cement paste and concrete were 120 and $200 \mathrm{~mm}$, respectively. The voltammetry was selected for the measurement of electrical resistance. Voltmeter and ammeter of specimens were collected with Victor 8246 desktop multimeter produced by Xi'an Shengli Instrument Co., Ltd., Xi'an, China. The electrical signal generator was DG822 function/arbitrary waveform generator produced by Puyuan Jingdian Technology Co., Ltd., Suzhou, China. The measurement of electrical resistance was shown in Figure 1. 


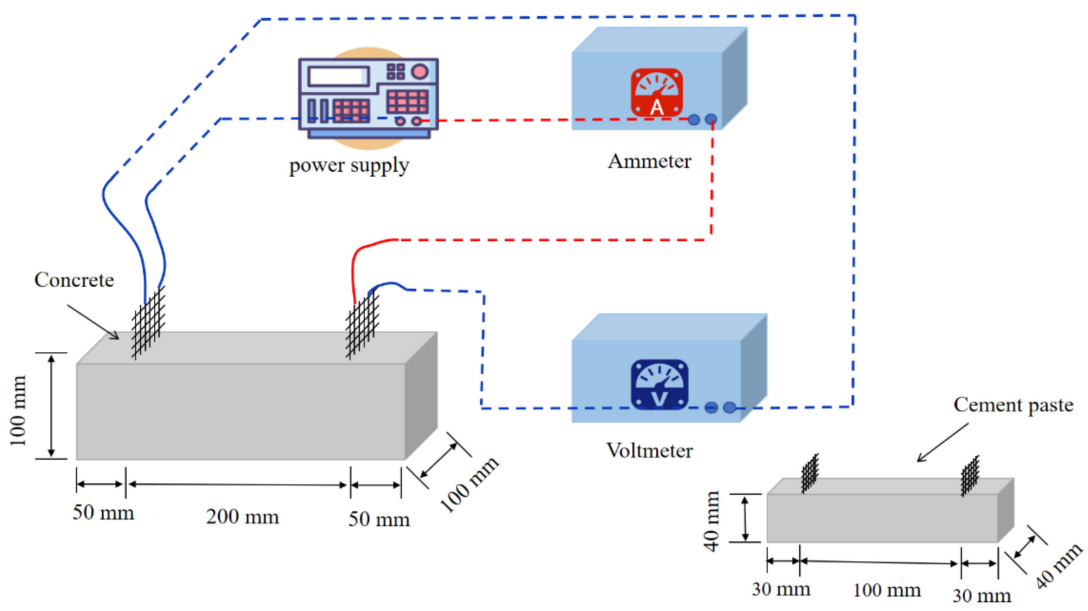

Figure 1. Measurement of electrical resistance.

\subsubsection{Measurement of Compressive Strength and Chloride Ion Permeability}

Concrete specimens with sizes of $100 \mathrm{~mm} \times 100 \mathrm{~mm} \times 100 \mathrm{~mm}$ and $\Phi 100 \mathrm{~mm} \times 50 \mathrm{~mm}$ were used for the measurement of compressive strength and chloride ion permeability parameters. The compressive strength of concrete was determined by Yaw-3000 microcomputer controlled electro-hydraulic servo pressure testing machine produced by Shanghai Sansi Zongheng Machinery Manufacturing Co., Ltd., Shanghai, China. Compressive strength was conducted according to Chinese standard GB/T 50081-2019 [27]. The loading rate for the compressive strength of concrete was $0.5 \mathrm{MPa} / \mathrm{s}$. For determining the chloride ion permeability parameters, the electric flux method was applied. Before the measurement, the specimens were soaked in the NEL-VJH type concrete vacuum machine manufactured by Beijing Nile instrument and Equipment Co., Ltd., Shanghai, China for $48 \mathrm{~h}$. After this step, the water saturated specimens were moved to the NEL-PDU type chloride diffusivity tester provided by Beijing Nile instrument and Equipment Co., Ltd., Shanghai, China. The $\mathrm{NaCl}$ solution with concentration of $3 \%$ and the $\mathrm{NaOH}$ solution with concentration of $0.3 \mathrm{~mol} / \mathrm{L}$ were applied in the cathode and anode, respectively. The experiment of chloride ion permeability parameters was carried out according to the Chinese Standard GB/T 50082-2009 [28].

\subsubsection{Experiments of SEM and XRD}

The process of SEM and XRD experiments can be described as follows:

The soybean size of hardened cement paste was taken from the inner specimens cured in the standard curing environment for 28 days, meanwhile, some other sample was ground into powder. The selected samples were immersed in the absolute ethanol for 4 days to prevent the hydration of cement. After that, all samples were dried in the vacuum drying oven produced by Shanghai Hecheng Instrument Manufacturing Co., Ltd., Shanghai, China at the temperature of $60{ }^{\circ} \mathrm{C}$ for 4 days. The dried samples were sprayed by gold before measurement. After these steps were finished, the SEM (Hitachi Limited., Tokyo, Japan) experiment was carried out. The ground powder of specimen was moved to the D8 ADVANCE X-ray diffractometer (Bruker Corp., Tokyo, Japan) for the measurement of the XRD.

\section{Results and Discussion}

\subsection{Electrical Resistivity}

Usually, the blank concrete cannot be used in the practical projects [29]. As described in some journals, the electrical resistivity can be used for the reflection of corrosion resistance of the inner metal materials of concrete [30]. Electrons from metallic materials in concrete can be difficult to move when the electrical resistivity of concrete was higher thus showing better corrosion resistance [31]. In this study, the electrical resistivity of cement-based 
materials was determined to reflect the corrosion resistance of inner metal reinforced materials. Figure 2 shows the electrical resistivity of cement paste and concrete with fly ash, GGBS, dolomites and iron tailings. As shown in Figure 2, the electrical resistivity increased in the form of quadratic function with the increasing curing age, due to the fact that the electrical resistivity of cement paste and concrete was dominated by the free ions of the pore solution [32,33]. The free water was decreased with the increasing curing ages due to the process in hydration thus reducing the free ions and the electrical conduction [34]. Therefore, the electrical resistivity increased with the curing age. Moreover, it could be observed from Figure 2, the addition of fly ash and GGBS led to increasing the electrical resistivity of cement paste and concrete. However, when the dolomites or iron tailings were added to the cement paste or concrete, the results were the opposite. This was attributed to the fact that the additions of mineral admixtures could accelerate the hydration process of cement thus decreasing the free water inner cement-based materials leading eventually to increasing the electrical resistivity of cement paste or concrete [35]. However, the dolomites and iron tailings possessing large amount of metal elements resulted in increasing free electrons of cement-based materials thus improving the electrical conduction and decreasing the following electrical resistivity [36]. The electrical resistivity of cement paste or concrete with fly ash was the highest, for the metallic elements of fly ash were the lowest. Table 4 shows the fitting results of the relationship between the electrical resistivity and the curing age. The fitting equation can be described in Equation (2). It can be depicted that, the fitting equations of electrical resistivity and the curing ages fits with quadratic function. As obtained from Table 4, the fitting degrees of all curves were higher than 0.86 , indicating that the fitting equation is reasonable.

$$
\rho=a t^{2}+b t+c
$$

where $a, b$ and $c$ are constants of the fitting equations, $t$ is the curing age.

Table 4. The fitting results between the electrical resistivity and mass ratios of mineral admixtures.

\begin{tabular}{|c|c|c|c|c|c|c|}
\hline $\begin{array}{c}\text { Mineral } \\
\text { Admixtures }\end{array}$ & Types & Content $/ \%$ & $a$ & $b$ & $c$ & $R^{2}$ \\
\hline \multirow{10}{*}{ Fly ash } & \multirow{5}{*}{ Cement paste } & 0 & $-2.6 \times 10^{-4}$ & 0.14 & 8.78 & 0.968 \\
\hline & & 5 & $-3.0 \times 10^{-5}$ & 0.22 & 7.73 & 0.998 \\
\hline & & 10 & $3.0 \times 10^{-5}$ & 0.24 & 7.52 & 0.999 \\
\hline & & 15 & $5.0 \times 10^{-5}$ & 0.27 & 7.31 & 0.998 \\
\hline & & 0 & $-5.3 \times 10^{-4}$ & 0.64 & 26.27 & 0.997 \\
\hline & \multirow{3}{*}{ Concrete } & 5 & $-1.0 \times 10^{-4}$ & 0.99 & 24.13 & 0.998 \\
\hline & & 10 & $-2.1 \times 10^{-4}$ & 1.27 & 21.81 & 0.999 \\
\hline & & 15 & $-2.7 \times 10^{-3}$ & 1.49 & 20.28 & 0.999 \\
\hline & \multirow{4}{*}{ Cement paste } & 0 & $-2.6 \times 10^{-4}$ & 0.14 & 8.78 & 0.968 \\
\hline & & 5 & $-6.0 \times 10^{-4}$ & 0.24 & 9.87 & 0.911 \\
\hline \multirow{6}{*}{ Slag } & & 10 & $-9.4 \times 10^{-4}$ & 0.31 & 10.75 & 0.869 \\
\hline & & 15 & $-1.0 \times 10^{-3}$ & 0.35 & 11.63 & 0.860 \\
\hline & \multirow{4}{*}{ Concrete } & 0 & $-5.3 \times 10^{-4}$ & 0.64 & 26.27 & 0.997 \\
\hline & & 5 & $6.3 \times 10^{-4}$ & 0.48 & 31.03 & 0.981 \\
\hline & & 10 & $-1.5 \times 10^{-4}$ & 0.94 & 33.03 & 0.967 \\
\hline & & 15 & $-3.0 \times 10^{-3}$ & 1.35 & 34.46 & 0.938 \\
\hline \multirow{8}{*}{$\begin{array}{c}\text { Dolomite rock } \\
\text { powder }\end{array}$} & \multirow{4}{*}{ Cement paste } & 0 & $-2.6 \times 10^{-4}$ & 0.14 & 8.78 & 0.968 \\
\hline & & 5 & $-1.1 \times 10^{-4}$ & 0.11 & 8.02 & 0.973 \\
\hline & & 10 & $-1.5 \times 10^{-4}$ & 0.11 & 7.80 & 0.981 \\
\hline & & 15 & $-2.1 \times 10^{-4}$ & 0.12 & 7.68 & 0.987 \\
\hline & \multirow{4}{*}{ Concrete } & 0 & $-5.3 \times 10^{-4}$ & 0.64 & 26.27 & 0.997 \\
\hline & & 5 & $-5.2 \times 10^{-3}$ & 1.57 & 31.57 & 0.925 \\
\hline & & 10 & $-4.5 \times 10^{-3}$ & 1.42 & 27.06 & 0.939 \\
\hline & & 15 & $-2.7 \times 10^{-3}$ & 0.99 & 38.15 & 0.953 \\
\hline
\end{tabular}


Table 4. Cont.

\begin{tabular}{ccccccc}
\hline $\begin{array}{c}\text { Mineral } \\
\text { Admixtures }\end{array}$ & Types & Content/\% & $\boldsymbol{a}$ & $\boldsymbol{b}$ & $\boldsymbol{c}$ & $\boldsymbol{R}^{\mathbf{2}}$ \\
\hline & & 0 & $-2.6 \times 10^{-4}$ & 0.14 & 8.78 & 0.968 \\
& Cement paste & 5 & $-1.5 \times 10^{-4}$ & 0.09 & 8.45 & 0.973 \\
Iron tailings & & 10 & $-3.9 \times 10^{-4}$ & 0.14 & 6.91 & 0.992 \\
& & 15 & $-2.9 \times 10^{-4}$ & 0.12 & 6.31 & 0.985 \\
& & 0 & $-5.3 \times 10^{-4}$ & 0.64 & 26.27 & 0.997 \\
& Concrete & 5 & $-3.0 \times 10^{-3}$ & 1.03 & 37.61 & 0.943 \\
& & 10 & $-2.2 \times 10^{-3}$ & 0.86 & 34.69 & 0.965 \\
& & $-2.0 \times 10^{-3}$ & 0.79 & 29.16 & 0.972 \\
\hline
\end{tabular}

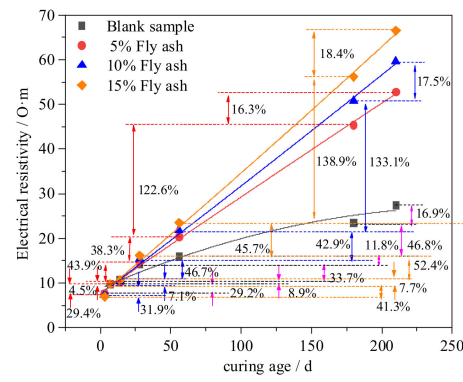

(a) Cement paste with fly ash.

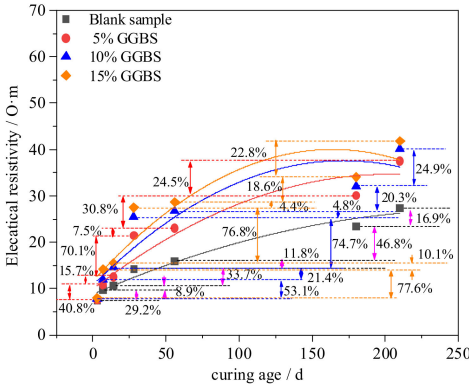

(c) Cement paste with GGBS.

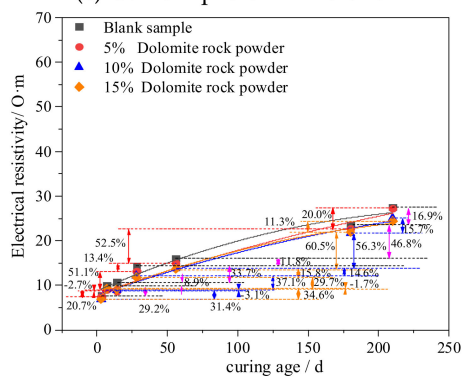

(e) Cement paste with dolomite rock powder.

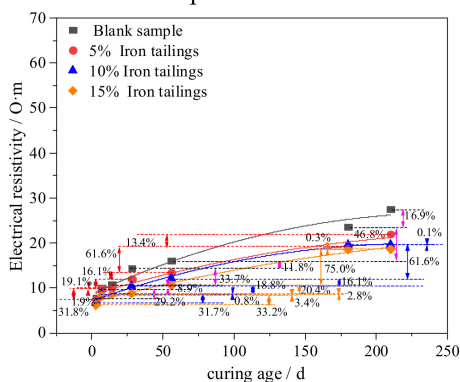

(g) Cement with iron tailings.

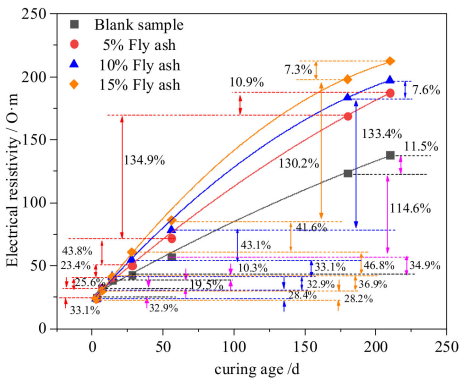

(b) Concrete with fly ash

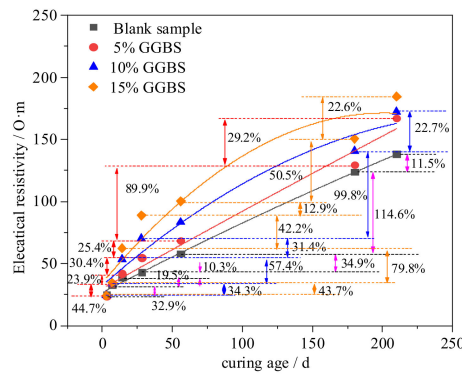

(d) Concrete with GGBS.

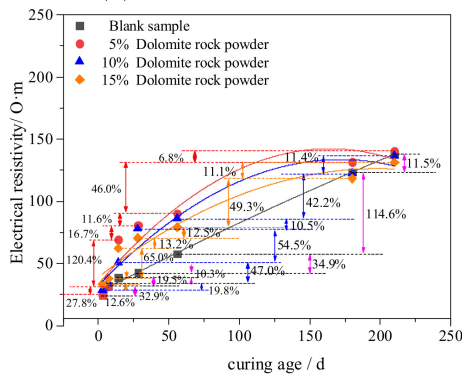

(f) Concrete with dolomite rock powder.

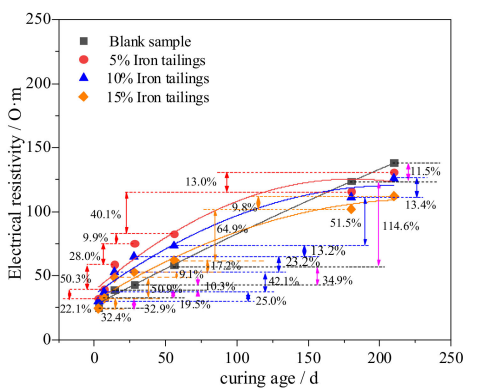

(h) Concrete with iron tailings.

Figure 2. Electrical resistivity of all specimens. 


\subsection{The Compressive Strength and Chloride Ion Permeability}

Figure 3 shows the compressive strength of concrete with different types and dosages of mineral admixtures. As depicted in Figure 3, the compressive strength of concrete decreased with the increasing dosages of fly ash, due to the fact that the existing defects in fly ash thus decreasing the compressive strength of concrete [37,38]. Moreover, when GGBS was added to the concrete, the compressive strength increased. This was attributed to the fact that the GGBS possessed large amount of $\mathrm{CaO}, \mathrm{Si}_{2} \mathrm{O}$ and $\mathrm{Al}_{2} \mathrm{O}_{3}$, leading eventually to accelerating hydration process of the concrete forming hydrated calcium silicate and hydrated calcium aluminate [39]. Therefore, the compressive strength of concrete was improved by the addition of GGBS. Furthermore, the compressive strength of concrete firstly increased and then decreased with the increasing dosages of dolomites and iron tailings. This was attributed to the fact that the filling effect of dolomites and iron tailings could improve the compactness of concrete, thus increasing the compressive strength of the concrete [40,41]. Moreover, the active substances of dolomites and iron tailings could promote the hydration of cement, thus improving the compressive strength [42]. However, the internal defects of dolomites and iron tailings could result in the decrease of the compressive strength $[43,44]$.

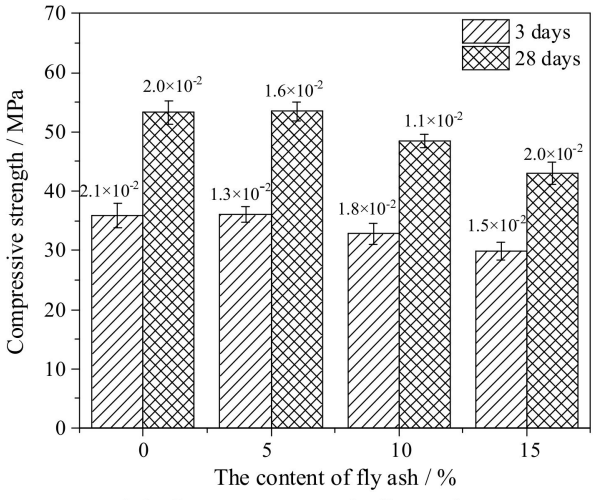

(a) Concrete with fly ash.

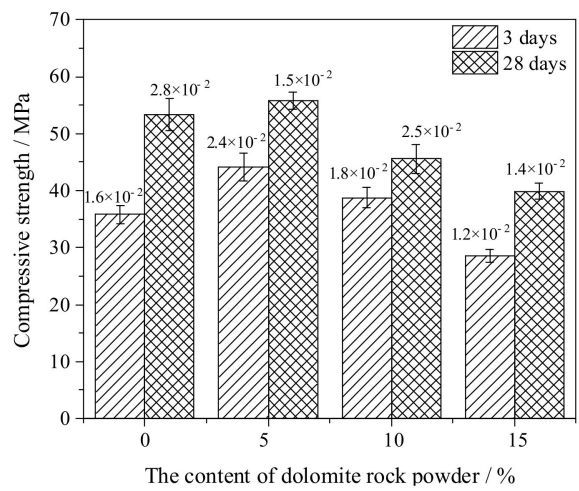

(c) Concrete with dolomite rock powder.

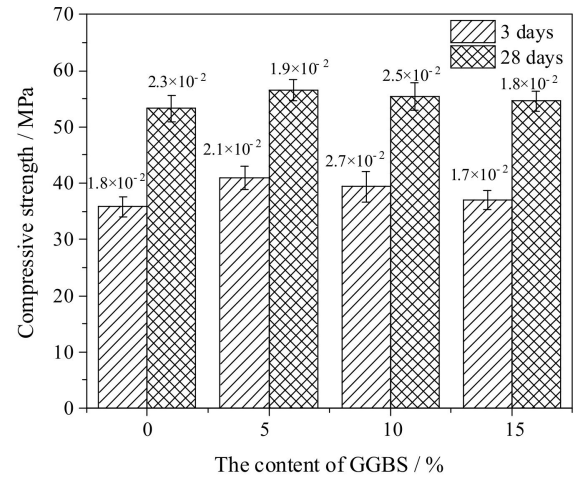

(b) Concrete with GGBS.

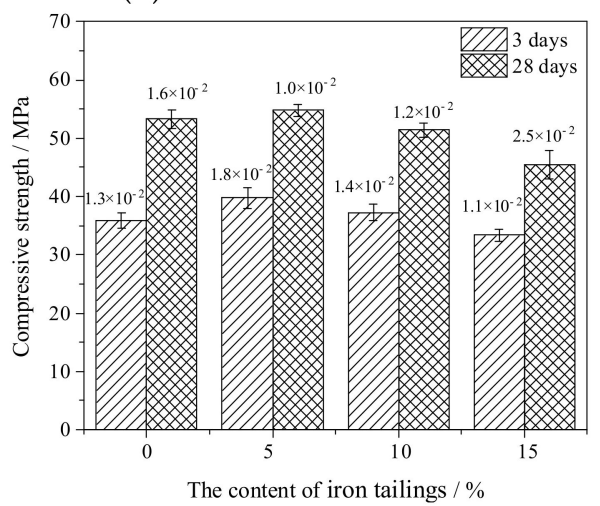

(d) Concrete with iron tailings.

Figure 3. Compressive strength of concrete.

Figure 4 shows the electric flux of concrete with different types and dosages of mineral additives. As observed from Figure 4, the electric flux of concrete decreased with the increasing curing age, indicating the decline in the chloride ion permeability of concrete. This was attributed to the fact that the increasing curing age led to the further development of hydration, thus improving the compactness of the internal structures of concrete and then decreasing the chloride ion permeability [45]. The electric flux of concrete decreased with the increasing dosages of fly ash and GGBS. However, when the dolomite rock powder and iron tailings were added, the electric flux of concrete firstly decreased and then increased with their increasing dosages. This signifies that the resistance of chloride ion permeability 
of concrete firstly increased and then decreased with the increasing dosages of dolomite rock powder and iron tailings $[19,21,46]$.

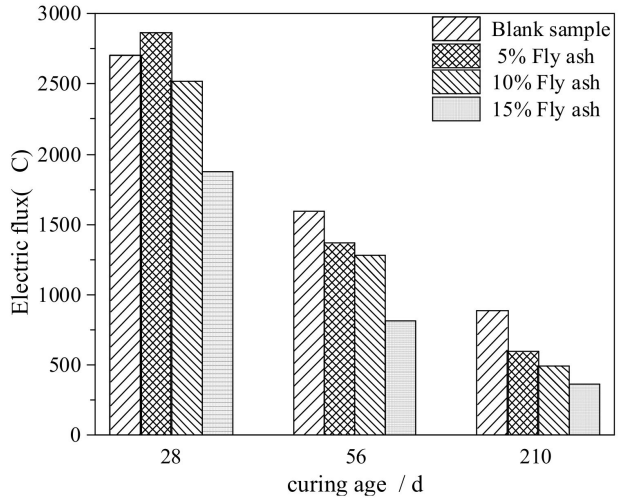

(a) Concrete with fly ash.

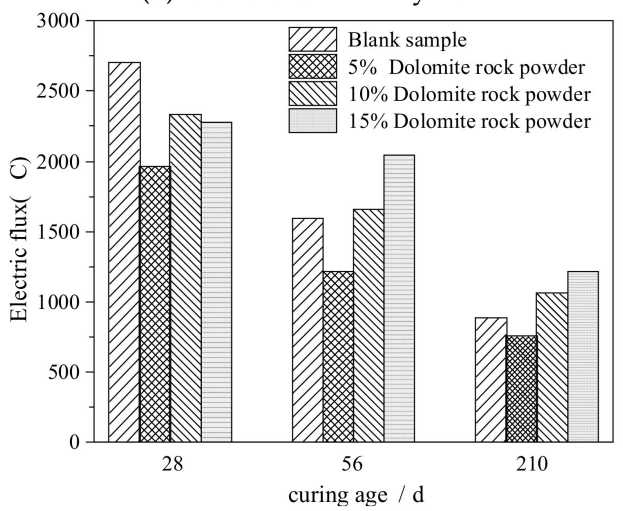

(c) Concrete with dolomite rock powder.

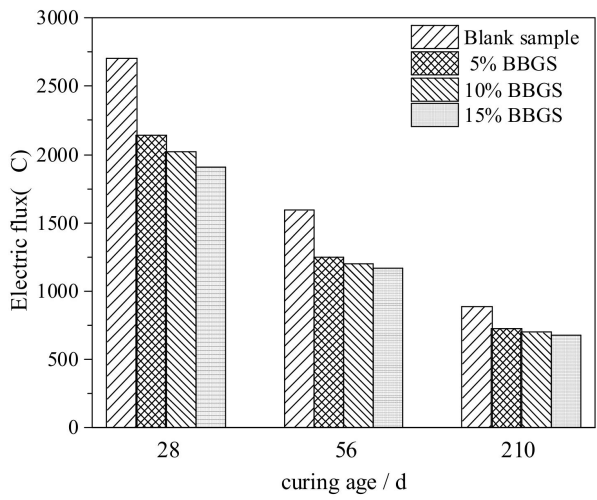

(b) Concrete with GGBS.

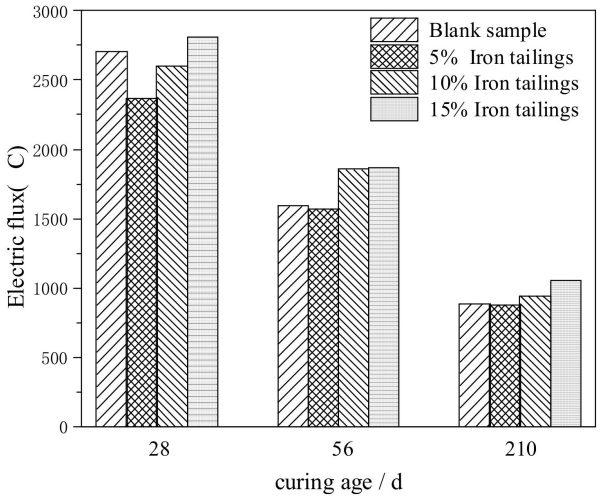

(d) Concrete with iron tailings.

Figure 4. Electric flux of all samples.

Figure 5 shows the relationship between the electric flux and electrical resistivity of concrete with different types and dosages of mineral admixures. As illustrated in Figure 5, the electric flux decreased in the form of quadratic function just expressed in Equation (3). Table 5 shows the fitting results. The fitting degrees of all curves were higher than 0.847 , indicating the rationality of the fitting functions.

$$
E_{f}=a \rho^{b}
$$

where $a$ and $b$ constants of the fitting equations, $E_{f}$ is the electric flux and $\rho$ is electrical resistivity.

\subsection{SEM and XRD Analysis}

The scanning electron microscope (SEM) was observed to investigate the effects of dolomite and iron tailings on the microstructures of cement paste. The samples for the determination of scanning electron microscope were firstly dried in the vacuum drying oven produced by Shanghai Hecheng Instrument Manufacturing Co., Ltd., Shanghai, China at the temperature of $60^{\circ} \mathrm{C}$ for 4 days. The dried samples were sprayed by gold before measurement. After the steps were finished, the SEM experiment was carried out. Figure 6 shows the SEM result of cement paste with different dosages of dolomites and iron tailings. As shown in this figure, the needle-like hydration products exist in the blank specimen. When $5 \%$ dolomite was added in the cement paste, the hydration products were more compact. However, when the dosage of dolomite was $15 \%$, more unhydrated particles could be found in the microstructure. Therefore, the compressive strength of concrete increased with the dosages of dolomites increasing from $0 \%$ to $5 \%$ and decreased with the dolomite increasing from $5 \%$ to $15 \%$. Moreover, when the content of iron tailings was $5 \%$, 
the hydration products were larger and more compact, thus improving the compressive strength of concrete. However, when the addition of iron tailings was $15 \%$, more pores were observed in the cement paste, thus confirming that the compressive strength was reduced when the content of iron tailings was $15 \%$.

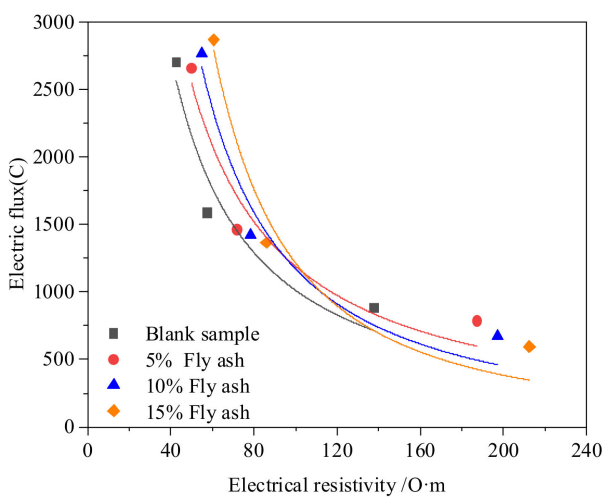

(a) Concrete with fly ash.

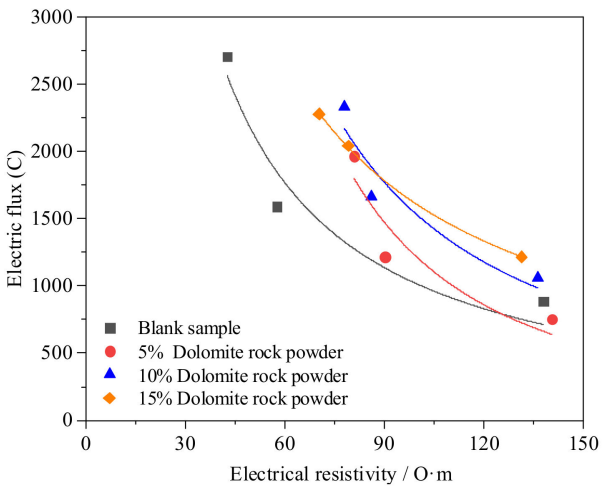

(c) Concrete with dolomite rock powder.

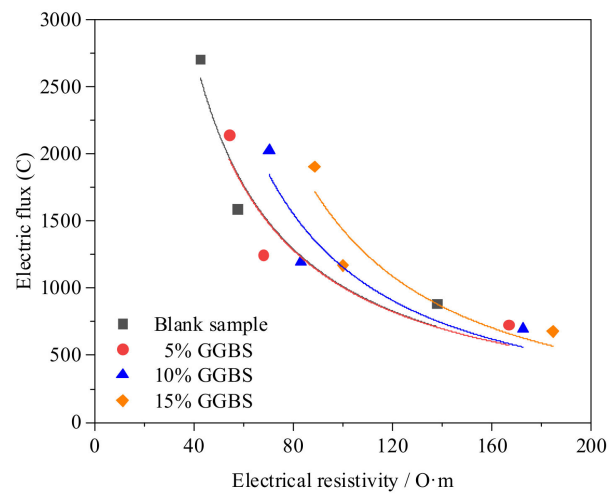

(b) Concrete with GGBS.

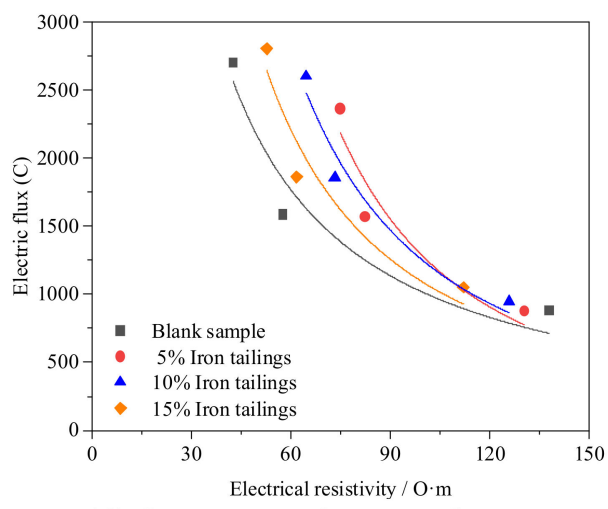

(d) Concrete with iron tailings.

Figure 5. Correlation between concrete electric flux and resistivity.

Table 5. The fitting results between electric flux and electrical resistivity of concrete.

\begin{tabular}{ccccc}
\hline Types & $\mathbf{M} / \%$ & $\boldsymbol{a}$ & $\boldsymbol{b}$ & $\boldsymbol{R}^{\mathbf{2}}$ \\
\hline \multirow{3}{*}{ Fly ash } & 0 & $1.5 \times 10^{5}$ & -1.09 & 0.931 \\
& 5 & $1.8 \times 10^{5}$ & -1.09 & 0.939 \\
& 10 & $6.5 \times 10^{5}$ & -1.37 & 0.956 \\
GGBS & 15 & $2.6 \times 10^{6}$ & -1.67 & 0.960 \\
& 0 & $1.5 \times 10^{5}$ & -1.09 & 0.931 \\
& 5 & $1.5 \times 10^{5}$ & -1.08 & 0.867 \\
Dolomite rock powder & 10 & $5.1 \times 10^{5}$ & -1.32 & 0.859 \\
& 15 & $1.52 \times 10^{5}$ & -1.51 & 0.847 \\
& 0 & $1.5 \times 10^{5}$ & -1.09 & 0.931 \\
Iron tailings & 5 & $6.7 \times 10^{6}$ & -1.87 & 0.862 \\
& 10 & $1.04 \times 10^{5}$ & -1.42 & 0.900 \\
& 15 & $1.7 \times 10^{5}$ & -1.01 & 0.999 \\
& 0 & $1.5 \times 10^{5}$ & -1.09 & 0.931 \\
& 5 & $7.0 \times 10^{6}$ & -1.87 & 0.900 \\
& 10 & $1.8 \times 10^{6}$ & -1.59 & 0.960 \\
& 15 & $6.6 \times 10^{5}$ & -1.39 & 0.930 \\
\hline
\end{tabular}




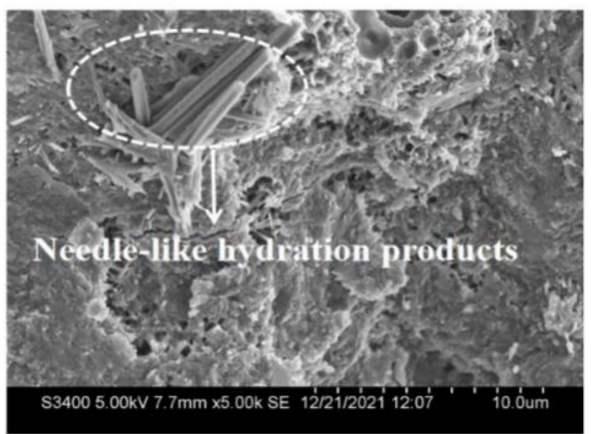

(a) Blank specimen.

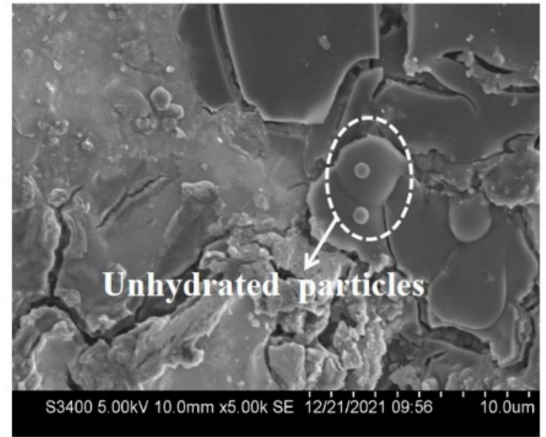

(c) With $15 \%$ dolomite rock powder.

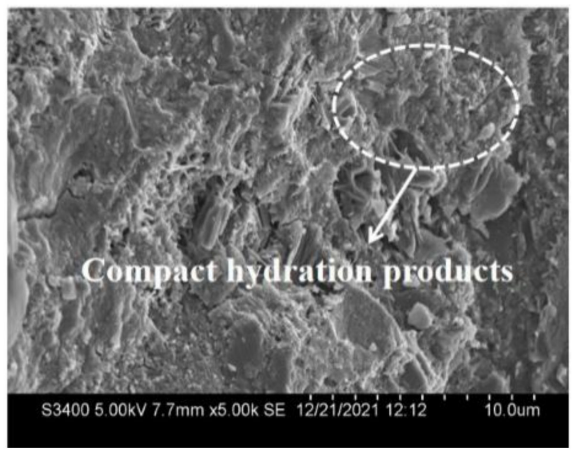

(b) With 5\% dolomite rock powder.

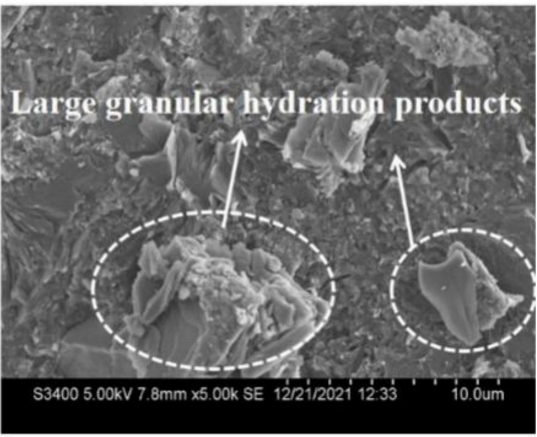

(d) With 5\% iron tailings.

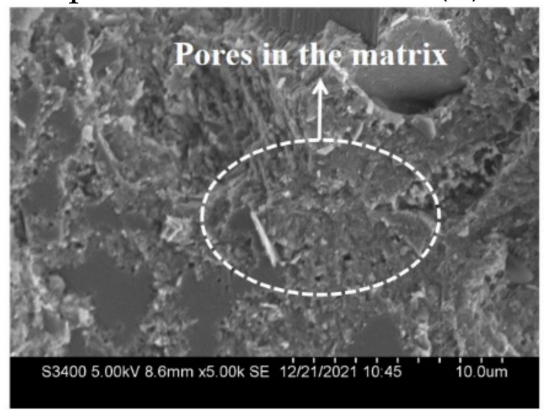

(e) With $5 \%$ iron tailings.

Figure 6. SEM microstructure photos of cement paste.

Figure 7 shows the X-ray diffraction (XRD) pattern photos of specimens containing different dosages of iron tailings and dolomite rock powder. The XRD experiment was carried out after the dried samples were ground into powder. It can be observed from Figure 7 that all the spectra show strong diffraction peaks of $3 \mathrm{CaO} \cdot \mathrm{SiO}_{2}\left(\mathrm{C}_{3} \mathrm{~S}\right), 2 \mathrm{CaO} \cdot \mathrm{SiO}_{2}$ $\left(\mathrm{C}_{2} \mathrm{~S}\right)$, cristobalite $\left(\mathrm{SiO}_{2}\right), \mathrm{Ca}(\mathrm{OH})_{2}$ and $\mathrm{CaCO}_{3}$. Moreover, as shown in Figure 7, the height of diffraction peak of $\mathrm{Ca}(\mathrm{OH})_{2}$ increased with the addition of iron tailings increasing from $0 \%$ to $5 \%$. However, when the addition of iron tailings increased from $5 \%$ to $15 \%$, the diffraction peak of $\mathrm{Ca}(\mathrm{OH})_{2}$ decreased. This was attributed to the fact that the active substances of iron tailings could improve the hydration of cement, thus consuming the $\mathrm{Ca}(\mathrm{OH})_{2}$ [18]. However, when the content of iron tailings increased from $5 \%$ to $15 \%$, the hydration of cement was insufficient, leading to increasing the content of $\mathrm{Ca}(\mathrm{OH})_{2}$, therefore the diffraction peak of $\mathrm{Ca}(\mathrm{OH})_{2}$ increased [47]. Furthermore, the increasing content of dolomite rock powder led to increasing the diffraction peak of $\mathrm{Ca}(\mathrm{OH})_{2}$ due to the fact that dolomite rock powder consisted of a large amount of $\mathrm{CaO}$, the $\mathrm{CaO}$ reacted with water and formed $\mathrm{Ca}(\mathrm{OH})_{2}$, thus increasing the diffraction peak of $\mathrm{Ca}(\mathrm{OH})_{2}$. 


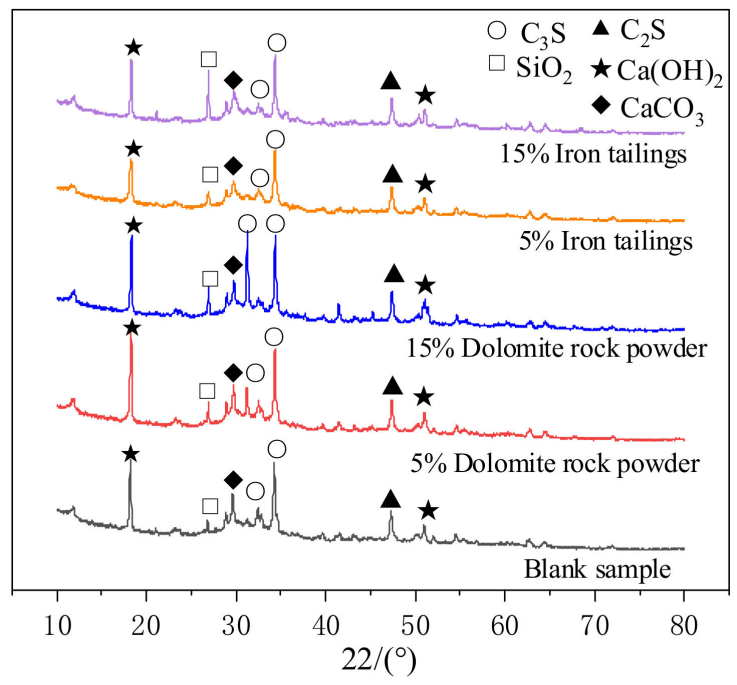

Figure 7. X-ray diffraction patterns of specimens.

\section{Conclusions}

In this study, the electrical and mechanical properties of cement paste and concrete with iron tailings and dolomite rock powder were studied. The results provide guidelines for the application of these two solid wastes in construction materials. The following conclusions can be summarized:

(1) The corrosion resistances of cement-based materials with different additives were determined by the electrical resistivity tests. The electrical resistivity of cement-based materials increases as a function of curing age, indicating the gradual solidification of free ions in cement over time. However, the electrical resistivity changes are highly sensitive to the chemical composition of additives.

(2) The addition of ground granulated blast-furnace slag can improve the compressive strength of concrete, however, fly ash will play an opposite effect. Additionally, the compressive strength of concrete exhibits an increase and then decrease trend with the increase of dolomites and iron tailings.

(3) The impermeability of chloride ions in concrete exhibits the first increase and then decrease trend with the increasing dosages of dolomite rock powder and iron tailings through the electric flux method.

(4) The microstructure of cement pastes can be compacted when adding a small dosage of dolomites or iron tailings (less than $5 \%$ ) due to the hydration promotion effect of additives. However, the microstructure of cement paste exhibits a deterioration with an excess content of dolomites or iron tailings, which is attributed to the internal defects of additives.

Author Contributions: Conceptualization, Y.L., W.H. (Wei He) and H.W.; methodology, Y.L.; software, W.H. (Wenru Hao); validation, Y.L. and W.H. (Wenru Hao); formal analysis, W.H. (Wei He) and X.M.; investigation, Y.S.; resources, Y.L. and W.H. (Wei He); data curation, W.H. (Wei He) and X.M.; writing-original draft preparation, W.H. (Wenru Hao), H.W., T.D. and W.H. (Wei He); writing-review and editing, H.W.; visualization, Y.L.; supervision, W.H. (Wei He) and Y.L. project administration, Y.L. and W.H. (Wei He); funding acquisition, Y.L. and W.H. (Wei He); All authors have read and agreed to the published version of the manuscript.

Funding: This work is sponsored by the Beijing Municipal Natural Science Foundation (No.8204058), Zhejiang Provincial Natural Science Foundation (No.Y22E081344), National Natural Science Foundation of China (No.51908022), China Postdoctoral Science Foundation (2019M660501), The Natural Science Foundation of Jiangsu Province (No. BK20200655), Program for Scientific Research of Beijing Education Commission (No.KM202110016013) and The Fundamental Research Funds for Beijing University of Civil Engineering and Architecture (No.X20032). 


\section{Institutional Review Board Statement: Not applicable.}

Informed Consent Statement: Not applicable.

Data Availability Statement: The data used to support the findings of this study are available from the corresponding author upon request.

Conflicts of Interest: The authors declare that there are no conflict of interest regarding the publication of this paper.

\section{References}

1. He, B.; Gao, Y.; Qu, L.; Duan, K.; Zhou, W.; Pei, G. Characteristics analysis of self-luminescent cement-based composite materials with self-cleaning effect. J. Clean. Prod. 2019, 225, 1169-1183. [CrossRef]

2. Mo, Z.; Gao, X.; Su, A. Mechanical performances and microstructures of metakaolin contained UHPC matrix under steam curing conditions. Constr. Build. Mater. 2021, 268, 121112. [CrossRef]

3. Chen, L.; Wang, Y.; Wang, L.; Zhang, Y.; Li, J.; Tong, L.; Hu, Q.; Dai, J.; Tsang, C.W. Stabilisation/solidification of municipal solid waste incineration fly ash by phosphate-enhanced calcium aluminate cement. J. Hazard. Mater. 2021, 408, 124404. [CrossRef]

4. Avila-López, U.; Almanza-Robles, J.M.; Escalante-García, J. Investigation of novel waste glass and limestone binders using statistical methods. Constr. Build. Mater. 2015, 82, 296-303. [CrossRef]

5. Vishwakarma, V.; Ramachandran, D. Green Concrete mix using solid waste and nanoparticles as alternatives-A review. Constr Build. Mater. 2018, 162, 96-103. [CrossRef]

6. Wang, L.; Luo, R.; Zhang, W.; Jin, M.; Tang, S. Effects of fineness and content of phosphorus slag on cement hydration, permeability, pore structure and fractal dimension of concrete. Fractals 2021, 29, 2140004. [CrossRef]

7. Ren, J.; Hu, L.; Dong, Z.; Tang, L.; Xing, F.; Liu, J. Effect of silica fume on the mechanical property and hydration characteristic of alkali-activated municipal solid waste incinerator (MSWI) fly ash. J. Clean. Prod. 2021, 295, 126317. [CrossRef]

8. Rehman, A.; Lee, S.; Kim, J. Use of municipal solid waste incineration ash in 3D printable concrete. Process Saf. Environ. Prot. 2020, 142, 219-228. [CrossRef]

9. Wang, L.; Guo, F.; Yang, H.; Wang, Y.; Tang, S. Comparison of fly ash, PVA fiber, MgO and shrinkage-reducing admixture on the frost resistance of face slab concrete via pore structural and fractal analysis. Fractals 2021, 29, 2140002. [CrossRef]

10. Papatzani, S.; Grammatikos, S.; Paine, K. Permeable Nanomontmorillonite and Fibre Reinforced Cementitious Binders. Materials 2019, 12, 3245. [CrossRef] [PubMed]

11. Papatzani, S.; Paine, K. A Step by Step Methodology for Building Sustainable Cementitious Matrices. Appl. Sci. 2020, 10, 2955 [CrossRef]

12. Alderete, N.M.; Joseph, A.M.; Heede, P.; Matthys, S.; Belie, N.D. Effective and sustainable use of municipal solid waste incineration bottom ash in concrete regarding strength and durability. Resour. Conserv. Recycl. 2021, 167, 105356. [CrossRef]

13. Wang, H.; Hu, L.; Cao, P.; Luo, B.; Tang, J.; Shi, F.; Yu, J.; Li, H.; Jin, K. The application of electrical parameters to reflect the hydration process of cement paste with rice husk ash. Materials 2019, 12, 2815. [CrossRef] [PubMed]

14. Yang, C.; Cui, C.; Qin, J.; Cui, X. Characteristics of the fired bricks with low-silicon iron tailings. Constr. Build. Mater. 2014, 70, 36-42. [CrossRef]

15. Yao, G.; Wang, Q.; Wang, Z.; Wang, J.; Lyu, X. Activation of hydration properties of iron ore tailings and their application as supplementary cementitious materials in cement. Powder Technol. 2020, 360, 863-871. [CrossRef]

16. Ding, Y.; An, P.; Cao, M. Study on Utilization of Waste Slate Powder as Mineral Admixture for Cement. J. Build. Mater. 2010, 13, 62-65.

17. Ye, G.; Liu, X.; Schutter, G.D.; Poppe, A.M.; Taerwe, T. Influence of limestone powder used as filler in SCC on hydration and microstructure of cement pastes. Cem. Concr. Compos. 2007, 29, 94-102. [CrossRef]

18. Han, F.; Song, S.; Liu, J.; Huang, S. Properties of steam-cured precast concrete containing iron tailing powder. Powder Technol. 2019, 345, 292-299. [CrossRef]

19. Han, F.; Luo, A.; Liu, J.; Zhang, Z. Properties of high-volume iron tailing powder concrete under different curing conditions. Constr. Build. Mater. 2020, 241, 118108. [CrossRef]

20. Lu, D.; Zhong, J.; Yan, B.; Gong, J.; He, Z.; Zhang, G.; Song, C. Effects of Curing Conditions on the MECHANICAL and Microstructural Properties of Ultra-High-Performance Concrete (UHPC) Incorporating Iron Tailing. Powder Technol. 2021, 14, 215. [CrossRef]

21. Song, S.; Zhang, L.; Li, Z. Effect of iron tailings micropow der on late-property of concrete. Concrete 2019, 128, 131-145. (In Chinese)

22. Wang, H.; Zhang, A.; Zhang, L.; Liu, J.; Han, Y.; Shu, H.; Wang, J. Study on the influence of compound rust inhibitor on corrosion of steel bars in chloride concrete by electrical parameters. Constr. Build. Mater. 2020, 262, 120763. [CrossRef]

23. Shi, W.; Wang, T.-Z.; Dong, Z.-H.; Guo, X.-P. Application of wire beam electrode technique to investigate the migrating behavior of corrosion inhibitors in mortar. Constr. Build. Mater. 2017, 134, 167-175. [CrossRef]

24. Ahmet, R.; Topcu, I.B. Influence of fly ash on corrosion resistance and chloride ion permeability of concrete. Constr. Build. Mater. $2012,31,258-264$. 
25. Shi, X.; Ning, X.; Fortune, K.; Jing, G. Durability of steel reinforced concrete in chloride environments: An overview. Constr. Build. Mater. 2012, 30, 125-138. [CrossRef]

26. GB/T 3048.2-2007; Test Methods for Electrical Properties of Electric Cables and Wires. China Standard Press: Beijing, China, 2007. (In Chinese)

27. GB/T 50081-2019; Standard for Test Methods of Physical and Mechanical Properties of Concrete. China Standard Press: Beijing, China, 2019. (In Chinese)

28. GB/T 50082-2009; Standard for Test Method of Long-Term Performance and Durability of Ordinary Concrete. China Standard Press: Beijing, China, 2009. (In Chinese)

29. Wang, H.; Jin, K.; Zhang, A.; Zhang, L.; Feng, L. External erosion of sodium chloride on the degradation of self-sensing and mechanical properties of aligned stainless steel fiber reinforced reactive powder concrete. Constr. Build. Mater. 2021, $287,123028$. [CrossRef]

30. Cui, L.; Wang, H. Research on the Mechanical Strengths and the Following Corrosion Resistance of Inner Steel Bars of RPC with Rice Husk Ash and Waste Fly Ash. Coatings 2021, 11, 1480. [CrossRef]

31. Wang, H.; Zhang, A.; Zhang, L.; Wang, Q.; Han, Y.; Liu, J.; Gao, X.; Shi, F.; Lin, X.; Feng, L. Hydration process of rice husk ash cement paste and its corrosion resistance of embedded steel bar. J. Cent. South Univ. 2020, 27, 11. [CrossRef]

32. Wang, H.; Gao, X.; Liu, J. Effects of salt freeze-thaw cycles and cyclic loading on the piezoresistive properties of carbon nanofibers mortar. Constr. Build. Mater. 2018, 177, 192-201. [CrossRef]

33. Layssi, H.; Ghods, P.; Alizadeh, A.R.; Salehi, M. Electrical Resistivity of Concrete. Concr. Int. 2015, 37, 41-46.

34. Cui, L.; Wang, H. Influence of Waste Fly Ash on the Rheological Properties of Fresh Cement Paste and the Following Electrical Performances and Mechanical Strengths of Hardened Specimens. Coatings 2021, 11, 1558. [CrossRef]

35. Kurda, R.; Brito, J.; Silvestre, J.D. Water absorption and electrical resistivity of concrete with recycled concrete aggregates and fly ash. Cem. Concr. Compos. 2018, 95, 169-182. [CrossRef]

36. Xue, J.; Wang, X.; Wang, Z.; Xu, S.; Liu, H. Investigations on influencing factors of resistivity measurement for graphite tailings concrete. Cem. Concr. Compos. 2021, 123, 104206. [CrossRef]

37. Nguyen, T.; Chatchawan, R.; Saengsoy, W.; Tangtermsirikul, S.; Sugiyama, T. Influences of different types of fly ash and confinement on performances of expansive mortars and concretes. Constr. Build. Mater. 2019, 209, 176-186. [CrossRef]

38. Zheng, J.; Liu, G. The Influence and Application of Slag, Fly Ash, and Limestone Flour on Compressive Strength of Concrete Based on the Concrete Compressive Strength Development Over Time (CCSDOT) Model. Appl. Sci. 2020, 10, 3572. [CrossRef]

39. Wu, M.; Sui, S.; Zhang, Y.; Jia, Y.; She, W.; Liu, Z.; Yang, Y. Analyzing the filler and activity effect of fly ash and slag on the early hydration of blended cement based on calorimetric test-Sciencedirect. Constr. Build. Mater. 2021, 276, 122201. [CrossRef]

40. Lu, C.; Ge, X.; Mei, G.; Liu, W.; Wang, H.; Yang, H. Study on hydration characteristics of dolomite powder in composite cementitious system. Concrete 2013, 11, 65-67. (In Chinese)

41. Li, T.; Wang, S.; Xu, F.; Meng, X.; Zhan, M. Study of the basic mechanical properties and degradation mechanism of recycled concrete with tailings before and after carbonation. J. Clean. Prod. 2020, 259, 120923. [CrossRef]

42. Cheng, Y.; Huang, F.; Li, W.; Liu, R.; Li, G.; Wei, J. Test research on the effects of mechanochemically activated iron tailings on the compressive strength of concrete. Constr. Build. Mater. 2016, 118, 164-170. [CrossRef]

43. Yazici, H. The effect of curing conditions on compressive strength of ultra high strength concrete with high volume mineral admixtures. Build. Environ. 2007, 42, 2083-2089. [CrossRef]

44. Wee, T.H.; Matsunaga, Y.; Watanabe, Y.; Sakai, E. Microstructure and strength properties of high strength concretes containing various mineral admixtures. Cem. Concr. Res. 1995, 25, 709-714. [CrossRef]

45. Thomas, M.; Bamforth, P.B. Modelling chloride diffusion in concrete: Effect of fly ash and slag. Cem. Concr. Res. 1999, 29, 487-495. [CrossRef]

46. Li, B.; Yi, L.; Feng, Z.; Fan, L.; Ye, X. Study on the effects of rock dust content on the durability of C60 mar ufactured sand marine concrete. Concrete 2017, 10, 169-173. (In Chinese)

47. Wu, R.; Shen, Y.; Liu, J.; Cheng, L.; Zhang, Y. Effect of Iron Tailings and Slag Powders on Workability and Mechanical Properties of Concrete. Front. Mater. 2021, 8, 723119. 